Coves of Departure 



\section{Coves of Departure}

Field Notes from the Sea of Cortez

John Seibert Farnsworth

Comstock Publishing Associates

an imprint of

Cornell University Press

Ithaca and London 
Copyright $(2018$ by John Seibert Farnsworth

All rights reserved. Except for brief quotations in a review, this book, or parts thereof, must not be reproduced in any form without permission in writing from the publisher. For information, address Cornell University Press, Sage House, 512 East State Street, Ithaca, New York 14850. Visit our website at cornellpress.cornell.edu.

First published 2018 by Cornell University Press

Printed in the United States of America

Library of Congress Cataloging-in-Publication Data

Names: Farnsworth, John Seibert, author.

Title: Coves of departure : field notes from the Sea of Cortez / John Seibert Farnsworth.

Description: Ithaca [New York] : Comstock Publishing Associates, an imprint of Cornell University Press, 2018. | Includes bibliographical references.

Identifiers: LCCN 2018021682 (print) | LCCN 2018022083 (ebook) | ISBN 9781501730191 (pdf) | ISBN 9781501730207 (epub/mobi) | ISBN 9781501730184 | ISBN 9781501730184 (pbk. ; alk. paper)

Subjects: LCSH: Natural history-Mexico—Baja California (Peninsula) | Natural history-Mexico-California, Gulf of. | Farnsworth, John Seibert-Travel-Mexico-Baja California (Peninsula) | Farnsworth, John Seibert-Travel-Mexico-California, Gulf of. | Baja California (Mexico : Peninsula)_Description and travel. | California, Gulf of (Mexico)—Description and travel.

Classification: LCC QH107 (ebook) | LCC QH107 .F37 2018 (print) | DDC 508.72/23-dc23

LC record available at https://lccn.loc.gov/2018021682

Cover illustration: Arch of Cabo San Lucas. Photograph (c) iStock.com. 
Dedicated to Carol 

Were it not for my field notes I should probably find it difficult to avoid confusing one island with another, one bay with another, and even one expedition with another.

Joseph Wood Krutch, The Forgotten Peninsula:

A Naturalist in Baja California, 1961 
